\title{
Differential involvement of DNases in HeLa cell apoptosis induced by etoposide and long term-culture
}

\author{
Alicia Torriglia ${ }^{\star, 1}$, Claudia Negri ${ }^{2}$, Elisabeth Chaudun', \\ Ennio Prosperi ${ }^{3}$, Yves Courtois ${ }^{1}$, Marie France Counis ${ }^{1}$ and \\ A. Ivana Scovassi ${ }^{2}$ \\ ${ }^{1}$ U450 INSERM, affiliée CNRS, Association Claude Bernard, 29, Rue Wilhem, \\ 75016 Paris, France \\ 2 Istituto di Genetica Biochimica ed Evoluzionistica CNR, Via Abbiategrasso 207, \\ 27100 Pavia, Italy \\ ${ }^{3}$ Centro di Studio per l'Istochimica CNR, Piazza Botta 10, 27100 Pavia, Italy \\ * corresponding author: Dr. Alicia Torriglia, U450 INSERM, affiliée CNRS, \\ Association Claude Bernard, 29, Rue Wilhem, 75016 Paris, France. \\ tel: +33-1-45252193; fax: +33-1-40500195; e-mail: torrigli@infobiogen.fr
}

Received 22.7.98; revised 4.11.98; accepted 25.11.98

Edited by J. Cidlowski

\begin{abstract}
We have applied to human HeLa cells two different stimuli of apoptosis: the antitumoral drug etoposide, and a more 'physiological' death condition, obtained by growing cells in the same medium for long time periods, for up to 10 days. Analysis of different parameters demonstrated that in both experimental systems the same apoptotic features are visible. However, the DNA degradation pattern appeared to be different, suggesting the involvement of different DNases. In this view, we have analyzed the activity and expression of $\mathrm{Ca}^{2+}-\mathrm{Mg}^{2+}$-dependent and acid DNases. We have observed that DNase I is not modulated during apoptosis. In contrast, the acid L-DNase II (derived from Leukocyte Elastase Inhibitor by post-translational modification), recently identified in our laboratory, is mainly active in the apoptotic pathway induced by long term-culture. Furthermore, we have provided evidence that while caspase 3 is activated by both inducers, caspase 1 is essential only for the etoposide-induced apoptosis.
\end{abstract}

Keywords: apoptosis; DNases; caspases; PARP proteolysis; etoposide

\begin{abstract}
Abbreviations: BSA, bovine serum albumin; CAD, caspase activated DNase; $\mathrm{CHO}$, chinese hamster ovary cells; CPAN, caspase activated nuclease; DAPI, 4',6-diamidino-2-phenylindole; FCS, fetal calf serum; ICAD, caspase activated DNase inhibitor; ICE, interleukin $1 \beta$-converting enzyme; LEI, leukocyte elastase inhibitor; PARP, poly(ADP-ribose) polymerase; PBS, phosphate buffered saline; PFGE, pulsed field gel electrophoresis; SDS, sodium dodecyl sulfate; TAE, tris-acetate EDTA buffer; TCA, trichloroacetic acid; TNF $\alpha$, tumor necrosis factor
\end{abstract}

\section{Introduction}

Apoptosis is a prevalent phenomenon in complex multicellular organisms. It is characterized by the deletion of scattered cells of a living tissue without disturbance of the continuity of tissue function. Apoptosis is accomplished by a process with a conserved phenotype, that strongly suggests a common underlying effector mechanism (for a review, see Vaux and Strasser $\left.{ }^{1}\right)$. This phenomenon presents a multistep DNA cleavage characterized by appearance of high molecular weight DNA molecules ${ }^{2,3}$ and oligonucleosomal fragments. ${ }^{4}$ The typical ladder was firstly described by Hewish and Burgoyne ${ }^{5}$ who demonstrated the $\mathrm{Ca}^{2+}, \mathrm{Mg}^{2+}$-dependent autodigestion of DNA in isolated liver cell nuclei. Based on this observation, it was widely considered that the endonuclease responsible for the internucleosomal DNA cleavage was $\mathrm{Ca}^{2+}, \mathrm{Mg}^{2+}$-dependent.

Since, several attempts have been made to identify the DNase(s) involved in apoptosis. A number of cationdependent endonucleases acting at neutral $\mathrm{pH}$ have been characterized, such as in thymocytes, NUC 18/cyclophili$\mathrm{n} \mathrm{A},{ }^{6}$ DNase I, ${ }^{7}$ DNase $\gamma^{8}$ and the new $92 \mathrm{KDa}$ DNase. ${ }^{9}$ In human myeloid cell lines, $\mathrm{Mg}^{2+}$-dependent, $\mathrm{Ca}^{2+}$-independent endonucleases have been identified. ${ }^{10,11}$ However, Barry and Eastman ${ }^{12}$ described in $\mathrm{CHO}$ cells a different endonuclease able to play a role in the apoptotic DNA digestion, that is the acid and non cation-dependent DNase II. This enzyme is activated by intracellular acidification which occurs during apoptosis. ${ }^{13,14}$

DNA is not the only macromolecule degraded during apoptosis. In fact, several proteins are cleaved by serine and cysteine proteases, which display their activity in the induction or in the execution phases of apoptosis. ${ }^{5}$ Among the targets of cysteine proteases, recently renamed 'caspases', ${ }^{16}$ the best described is the nuclear enzyme poly(ADP-ribose) polymerase (PARP), which is converted from the $116 \mathrm{KDa}$ form to 89 and $24 \mathrm{KDa}$ fragments. ${ }^{17}$ PARP proteolysis is carried out by caspase 3 family, including CPP32, apopain, Yama, and probably caspase 7 (for a review, see Cohen; Thornberry and Lazebnik $\left.^{18,19}\right)$. Synthetic peptides inhibiting these caspase activities are widely used to implicate different caspases in different apoptotic pathways. ${ }^{20}$ For instance the synthetic DEVD peptide is currently used to inhibit caspase 3 , while YVAD or ZVAD are commonly used to inhibit the caspase 1 family of proteases, including ICE (interleukin $1 \beta$-converting enzyme). Very recently, a relationship betwen caspases and endonucleases has been reported, suggesting the existence of a caspase-activated DNase (CAD), ${ }^{21}$ regulated by a specific inhibitor, ICAD. ${ }^{22}$ A novel caspase-activated nuclease (CPAN) has been also described in Jurkat cells. ${ }^{23}$

We have reported that DNase II is implicated in apoptotic DNA degradation occurring during chick lens cell differentiation. ${ }^{24}$ By a further characterization of this DNase II, we have recently shown that this $27 \mathrm{KDa}$-peptide is derived, by a post-translational modification, from a precursor of $42 \mathrm{KDa}$. This precursor, in its native form, is identical to the Leukocyte Elastase Inhibitor (LEI). The anti- 
protease activity of $\mathrm{LEI}$ is lost during its conversion to active DNase II. As this DNase II is different from other DNases II already described, ${ }^{25,26}$ and it is derived from LEI, we named it L-DNase II and we have demonstrated its involvement during apoptosis. ${ }^{27}$

The aim of this study was to compare different morphological and biochemical parameters of apoptosis, including DNase activation in cells driven to apoptosis by different stimuli. To do this, we have used the human tumoral HeLa cells either treated with etoposide, a drug inhibiting topoisomerase II and widely used in cancer therapy, or long term-cultured with no medium change, allowing growth factor depletion.

We have evaluated DNase activity and expression. From our data, two pathways of genome cleavage can be distinguished. L-DNase II and $\mathrm{Ca}^{2+}-\mathrm{Mg}^{2+}$-dependent DNases, other than DNase I, appeared to be involved in the induction of apoptosis by long term-culture but not in etoposide-induced apoptosis. DNase I contributes for a minor account to DNA cleavage in both apoptotic systems. Moreover, the induction of apoptosis seemed to follow different pathways to activate DNases, L-DNase II being activated by an ICE-independent pathway. However, experiments carried out with the inhibitor of caspase 1 revealed that this enzyme is essential only for the etoposide-induced apoptosis. To investigate the involvement of caspases in HeLa cell apoptosis, we examined PARP proteolysis as a marker of caspase activity. Since the best PARP-degrading enzymes belong to group 3 , we argue that caspase 3 is activated during HeLa cells apoptosis.

\section{Results}

\section{Morphology of apoptotic cells}

The morphology of etoposide-treated and of long termcultured HeLa cells was analyzed by DNA staining with the fluorochrome Hoechst 33258. Results of a typical experiment are illustrated in Figure 1. After $3 \mathrm{~h}$ of exposure to $100 \mu \mathrm{M}$ etoposide followed by culture in drug-free medium for $3 \mathrm{~h}$ (recovery), chromatin fragmentation and condensation were evident in about $8 \%$ of cells (Figure 1B). The number of cells with an apoptotic phenotype was increased after a longer recovery period reaching a maximum of $31 \%$ (24 h; Figure $1 \mathrm{C)}$.

In long term-culture experiments, we found that cells showed a normal nuclear morphology after 4 days of culture (Figure 1D), while typical apoptotic features were observed in $12 \%$ of cells after 7 days in the same medium (Figure 1E). This phenomenon was more evident in cell cultures maintained for up to 10 days in the same culture medium (Figure 1F, 43\%). As an effect of etoposide treatment followed by $24 \mathrm{~h}$ of recovery and of 10 days culture, a fraction of cells detached from the Petri dish and floated. Most of floating cells exhibited apoptotic features, while still adherent cells were characterized by about $5 \%$ of apoptosis (not shown). No morphological difference has been observed in apoptotic cells with respect to the inducer of apoptosis.
A
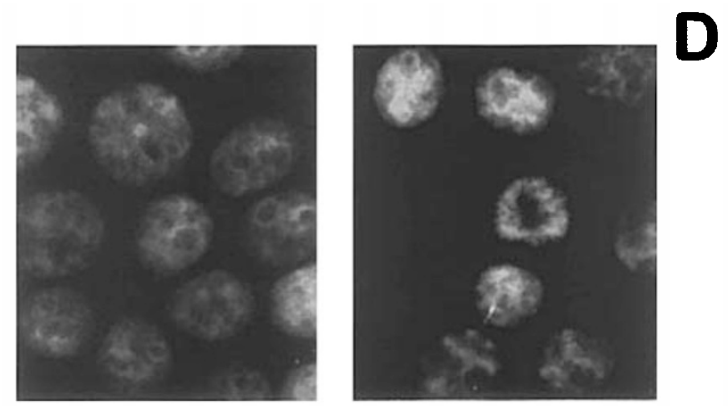

B
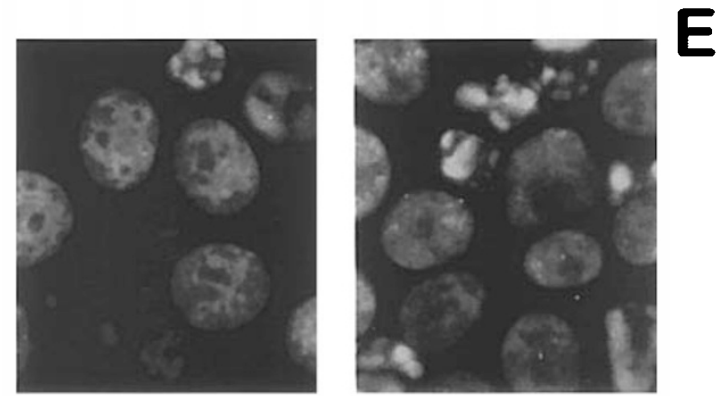

C
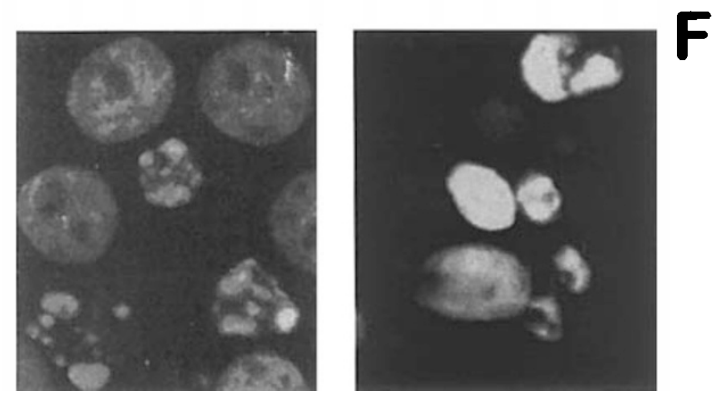

Figure 1 Analysis of nuclear morphology of HeLa cells treated with etoposide or long term-cultured. Nuclear morphology was analyzed in each different sample by staining with Hoechst33258. (A) Control cells. (B) Cells treated with $100 \mu \mathrm{M}$ etoposide for $3 \mathrm{~h}$ and incubated with fresh medium for 3 additional hours. (C) Cells treated with $100 \mu \mathrm{M}$ etoposide for $3 \mathrm{~h}$ and further incubated with fresh medium for $24 \mathrm{~h}$. (D-F) HeLa cells cultured without changing of the medium for up to 4 days (D), 7 days (E) or 10 days (F)

\section{Flow cytometry}

Cells showing a DNA content lower than the $2 \mathrm{C}$, which is typical of the $G_{1}$ peak, were defined as cells in the sub $\mathrm{G}_{1-A_{0}}$ region. Figure 2 illustrates the cell cycle distribution of control cells (Figure 2A), of cells treated for $3 \mathrm{~h}$ with $100 \mu \mathrm{M}$ etoposide and further incubated for $24 \mathrm{~h}$ in fresh medium (Figure 2B) and of cells cultured up to 9 days without changing of the medium (Figure 2C). The effect of drug-treatment analyzed by flow cytometry revealed the appearance of propidium iodide-stained DNA in the sub-G $\mathrm{G}_{1}$ region, corresponding to cells showing DNA fragmentation or condensation. No evidence of material typical of necrotic cells was observed. As indicated in panel $B$, the $A_{0}$ region accounted for about $40 \%$ of total DNA.

As the age of the culture increased from 4 to 9 days, the percentage of cells in $A_{0}$ phase was considerably 
A

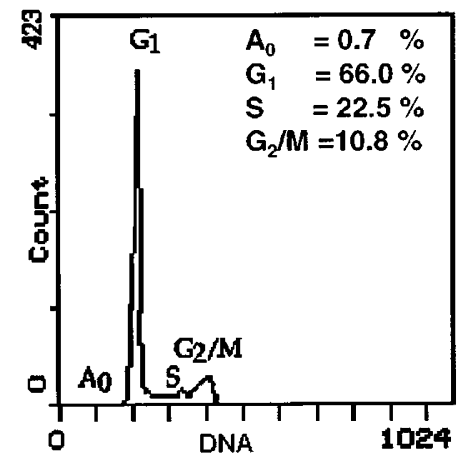

B

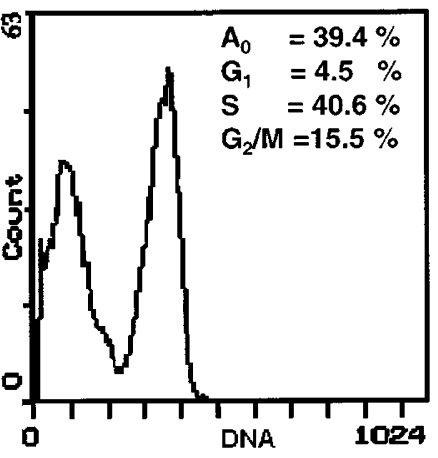

C

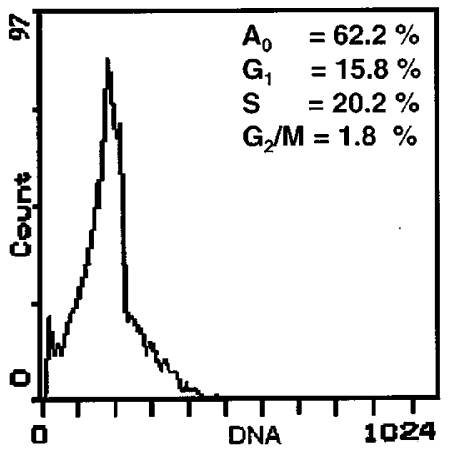

Figure 2 Flow cytometry analysis of HeLa cells treated with etoposide or long term-cultured. DNA was stained with propidium iodide and its content determined by flow cytometry. Data are expressed as the percentage of cells in each phase and represent the average of two independent experiments. (A) Control cells. (B) Cells treated with $100 \mu \mathrm{M}$ etoposide for $3 \mathrm{~h}$ and incubated with fresh medium for 24 additional hours. (C) HeLa cells cultured in the same medium for up to 9 days

higher, reaching about $31 \%$ at 7 days (not shown) and $55 \%$ at 9 days (C). The presence of cells in the sub- $\mathrm{G}_{1}$ region indicates that apoptotic DNA degradation and/or condensation occurred in long term-cultured cells as well as in cells incubated with etoposide. The fraction of cells in the $A_{0}$ region is higher than the number of cells with apoptotic phenotype; this discrepancy can be explained by an overestimation of cells in the $A_{0}$ region. In fact, in the $A_{0}$ peak early apoptotic cells (which cannot be easily visualized under light microscopy) as well as fragmented cells may be included. The comparison between the DNA content profiles obtained from etoposide-treated and longterm cultured cells, showed, in both samples, a marked increase of cells in the sub $\mathrm{G}_{1}$ region. However, it is evident that the topoisomerase inhibitor interfers with the cell cycle by inducing an accumulation of cells in the $S / G_{2}$ phases. In contrast, growth factor deprivation caused a clear cell loss from the $\mathrm{G}_{1}$ and $\mathrm{G}_{2}$ compartments. Although the number of cells present in the S-phase was not significantly different from control samples, these cells are also committed to die, as indicated by their decrease in light scatter (not shown).

\section{DNA fragmentation}

To compare whether two different apoptotic stimuli could induce, in HeLa cells, the same pattern of DNA fragmentation, we analyzed DNA size, using pulsed field (PFGE) and conventional gel electrophoresis.

HeLa cells were treated with $100 \mu \mathrm{M}$ etoposide for $3 \mathrm{~h}$ and harvested either immediately or after 3 and $24 \mathrm{~h}$ of recovery in fresh medium. DNA was analyzed by PFGE and, in parallel, by conventional gel electrophoresis. As shown in Figure $3 \mathrm{~A}$, a 3 h-etoposide treatment was sufficient to produce high molecular weight DNA molecules ranging from 600 to $50 \mathrm{~Kb}$ (lane 2). These molecules were still present, even at lower extent, in samples harvested after a 3 h-recovery in drug-free medium (lane 3) and disappeared after prolonged recovery periods ( $24 \mathrm{~h}$, lane 4). DNA extraction from etoposide-treated cells revealed a ladder (Figure 3A, lanes 5-8) whose intensity was lower in cells harvested immediately after drug administration (lane $6)$, while it increased proportionally with recovery time periods (lanes 7 and 8, corresponding to 3 and $24 \mathrm{~h}$, respectively).

We extended DNA analysis to cells maintained in culture for increasing times for up to 10 days in the same medium (Figure $3 \mathrm{~B}$ ). In this case, PFGE analysis showed detectable high molecular weight DNA fragmentation with a kinetics different from etoposide. As illustrated in Figure 3B, DNA molecules of high molecular weight were slightly visible after 7 days of cell culture (lane 2) and were followed later on by the appearance of DNA molecules of size lower than $50 \mathrm{~Kb}$ (lane 3). In the same cultures, the pattern of internucleosomal DNA fragmentation, visible as fragments multiple of about $180 \mathrm{bp}$ appeared after 7 days in culture (lane 6). The intensity of DNA ladder was clearly increased after a longer treatment (9 days), suggesting a time-dependent DNA degradation (lane 7).

\section{PARP proteolysis and activity}

Poly(ADP-ribose) polymerase (PARP) is the best described target of proteolysis during apoptosis. ${ }^{18}$ Extracts from drugtreated or long term-cultured cells have been analyzed by Western blot with the monoclonal antibody C-2-10 directed against an epitope located within the catalytic domain and the DNA binding domain, which is able to recognize the intact PARP and its $89 \mathrm{KDa}$ fragment. The analysis has been performed on still viable, adherent cells, and on floating cells harvested both after etoposide treatment and long termculture. The analysis of attached and floating cells by microscopy after DAPI staining showed a significant difference $(P<0.05)$ in the number of apoptotic cells. Apoptotic cells were mostly seen in the floating fraction (Table 1).

A typical result of Western blot for PARP is shown in Figure 4. It is evident (Figure 4A) that in the attached cell population only the $116 \mathrm{KDa}$ molecule is visible. However, when the analysis was performed on the floating apoptotic cell fraction, harvested after etoposide treatment or long 

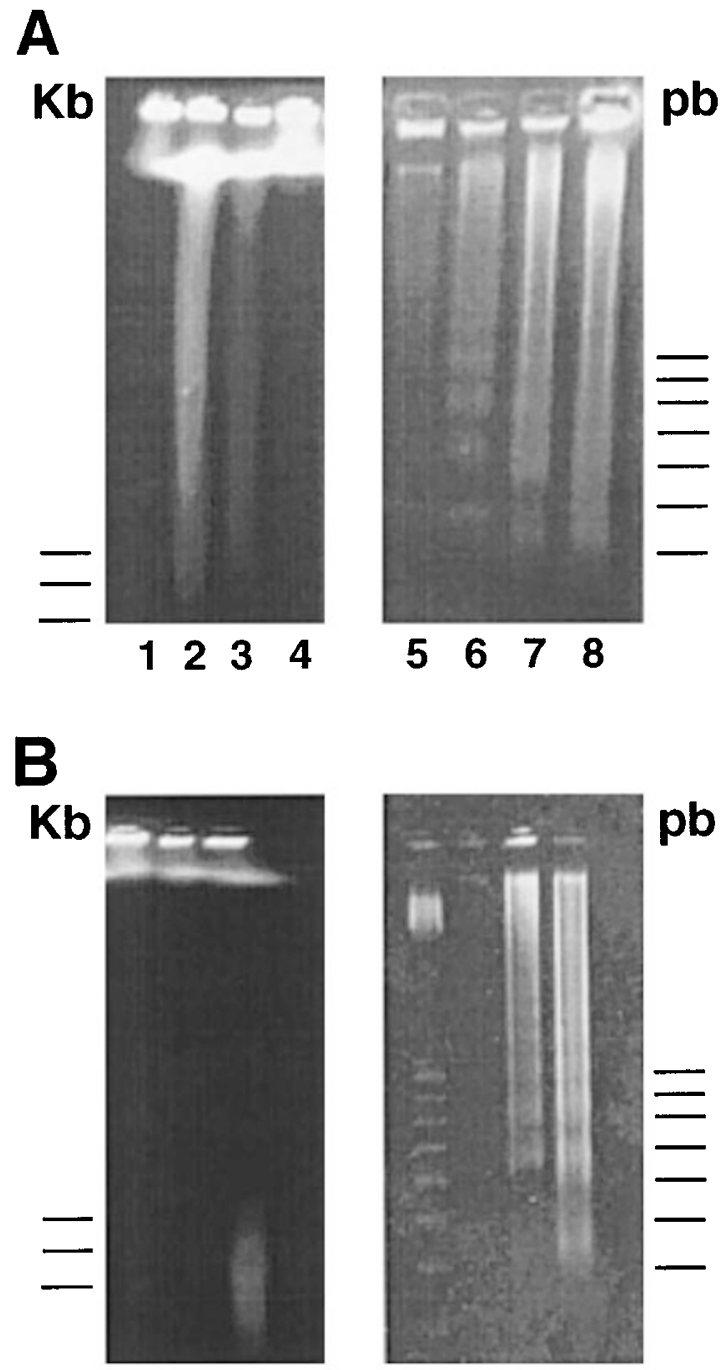

123

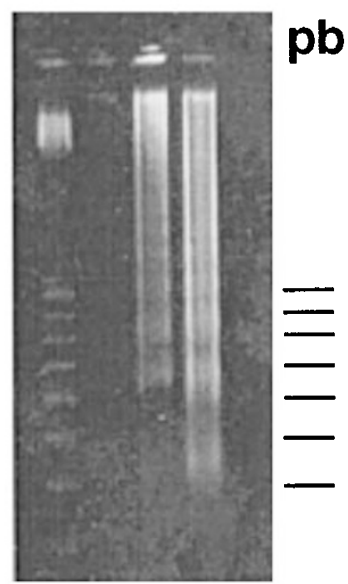

$\begin{array}{llll}4 & 5 & 6 & 7\end{array}$

Figure 3 Analysis of high molecular weight DNA fragments and internucleosomal DNA cleavage. (A) HeLa cells treated with etoposide. Lanes 1-4, DNA analyzed by PFGE; lanes 5-8: conventional agarose gel electrophoresis. Lanes 1 and 5: control cells, lanes 2 and 6: cells treated with $100 \mu \mathrm{M}$ etoposide for $3 \mathrm{~h}$; lanes 3 and 7 : cells treated with $100 \mu \mathrm{M}$ etoposide for $3 \mathrm{~h}$ followed by $3 \mathrm{~h}$ of recovery in fresh medium; lanes 4 and 8 : cells treated with $100 \mu \mathrm{M}$ etoposide for $3 \mathrm{~h}$ followed by $24 \mathrm{~h}$ of recovery in fresh medium. (B) Long term-cultured HeLa cells. Lanes 1-3, DNA analyzed by PFGE; lanes 46: conventional agarose gel electrophoresis. Lanes 1 and 5: cells incubated in the same medium for 4 days; lanes 2 and 6: cells incubated in the same medium for 7 days; lanes 3 and 7: cells incubated in the same medium for up to 9 days. Lane 4: molecular weight standards. PFGE MW markers: 21 successive concatamers of lambda DNA. The lowest band represents $48.5 \mathrm{~Kb}$. Ladder MW markers: molecular weight marker IV DNA, the lowest band represents $180 \mathrm{bp}$

term-culture, intact PARP was no longer evident, being converted to its $89 \mathrm{KDa}$ fragment.

The autoribosylation capacity of PARP analyzed by activity gel revealed that the intact protein displays a very high activity (Figure 4B, attached cells). The full conversion of PARP in floating cells was also proved by the faint autoradiographic band shown by the activity gel autoradio-

Table 1 Apoptotic index of attached and floating HeLa cells, treated with etoposide or cultured without changing the culture medium

\begin{tabular}{lrrrr}
\hline & \multicolumn{2}{c}{ Cell number (\%) } & \multicolumn{2}{c}{ Apoptotic index (\%) } \\
Attached & \multicolumn{1}{c}{$\begin{array}{c}\text { Floating } \\
\text { cells }\end{array}$} & \multicolumn{1}{c}{ cells } & \multicolumn{1}{c}{ Attached } \\
cells & \multicolumn{1}{c}{$\begin{array}{c}\text { Floating } \\
\text { cells }\end{array}$} \\
\hline Treatment & & & & \\
\hline Etoposide+recovery & & & & \\
$3 \mathrm{~h}+3 \mathrm{~h}$ & $90.8 \pm 1.0$ & $9.1 \pm 1.0$ & $4.3 \pm 0.2$ & $10.1 \pm 0.6$ \\
$3 \mathrm{~h}+24 \mathrm{~h}$ & $75.3 \pm 1.0$ & $24.7 \pm 1.0$ & $26.0 \pm 1.5$ & $49.1 \pm 1.9$ \\
Long term culture (days) & & & \\
5 & $90.0 \pm 1.0$ & $9.5 \pm 1.0$ & $2.4 \pm 0.3$ & $5.6 \pm 0.4$ \\
6 & $77.3 \pm 1.7$ & $22.7 \pm 1.7$ & $2.5 \pm 0.4$ & $7.5 \pm 0.4$ \\
7 & $68.3 \pm 3.3$ & $31.7 \pm 3.3$ & $8.8 \pm 0.9$ & $23.3 \pm 1.4$ \\
8 & $30.0 \pm 2.4$ & $70.0 \pm 2.3$ & $27.0 \pm 0.7$ & $73.0 \pm 2.7$ \\
\hline
\end{tabular}

HeLa cells were treated for $3 \mathrm{~h}$ with $100 \mu \mathrm{M}$ etoposide and further incubated for 3 or $24 \mathrm{~h}$ in fresh medium. For long term-culture experiments, cells were grown in the same medium for increasing periods of time, for up to 8 days. Attached and floating cells were recovered separately and counted by a hemocytometer. To evaluate the amount of apoptotic cells, samples were stained with Hoechst 33258. The number of apoptotic cells over the total cell number represents the apoptotic index which is expressed as percentage. Statistical analysis was applied to the data from three independent experiments

graphy (Figure 4B). These data strongly support the involvement of caspase 3 and/or 7 in both apoptotic conditions, leading to the complete proteolysis and, by consequence, to the inactivation of PARP.

\section{DNase activation}

We have shown that in HeLa cells, different apoptotic stimuli led to DNA degradation. To verify is the same DNase was implicated, we measured the activity of DNases which have already been reported to play a role during chick lens apoptosis, e.g. DNases $\mathrm{Ca}^{2+}-\mathrm{Mg}^{2+}$-dependent, acid DNases, and $\mathrm{Mg}^{2+}$-dependent DNases (Figure 5A). In etoposidetreated cells, we observed an overall decrease in the enzyme specific activity. In contrast, in apoptosis induced by long termculture we found an increase of both $\mathrm{Ca}^{2+}-\mathrm{Mg}^{2+}$-dependent and acid DNases. For $\mathrm{Ca}^{2+}-\mathrm{Mg}^{2+}$ DNases, a maximum of activity is observed at day 6 , while the activity of acid DNase is still increasing (not shown). To further elucidate this phenomenon, we analyzed separately the two cell populations resulting from the apoptosis induction: the attached cells, which were enriched in living cells, and the floating cells, which were enriched in apoptotic cells (Figure 5B). In both populations, we found an increase of the DNase activities starting at 4 days of culture and reaching a plateau until day 8 . In floating cells, the activity exhibited a maximum at day 6 .

\section{DNase expression}

To further investigate the activation of specific DNases in apoptosis, we followed the expression of two DNases using immunochemical techniques. $\mathrm{Ca}^{2+}-\mathrm{Mg}^{2+}$-dependent DNases were investigated using a commercial available antibody directed against DNase I. DNase I from HeLa cells was not recognized in Western blot (not shown). Acid endonucleases were followed using a polyclonal antibody to L-DNase II prepared in our laboratory. ${ }^{24}$ Anti-L-DNase II showed a major band of about $25 \mathrm{KDa}$ (Figure 6), the expected size for human DNase II, which presents an apparent molecular weight lower 
than porcine DNase II, used as control. The intensity of this $25 \mathrm{KDa}$ band did not change in etoposide-treated cells. In contrast, it was increased in long term-cultured cells, reaching a peak after 6 days of culture. It is interesting to note the presence of an immunoreactive band of $42 \mathrm{KDa}$ in samples harvested at day 4 by trypsinization (attached cells). The molecular weight of this immunoreactive band corresponds to the molecular weight of leukocyte elastase inhibitor, the precursor of L-DNase II, which we had recently cloned. ${ }^{27}$
The expression and subcellular localization of these enzymes, were further assessed by immunocytochemistry. Anti-DNase I and anti-L-DNase II reaction was developed using an anti-rabbit IgG-rhodamine isothiocyanate-conjugated. In the same samples, HeLa cell nuclear morphology was visualized by DAPI staining (Figure 7). No difference was observed in the expression of DNase I or L-DNase II between living and apoptotic cells (arrows) when apoptosis was induced by the topoisomerase inhibitor, etoposide.
A

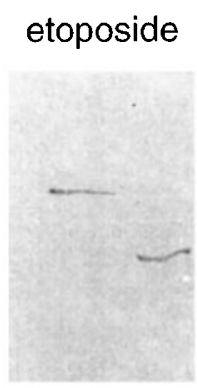

A $F$ long-term

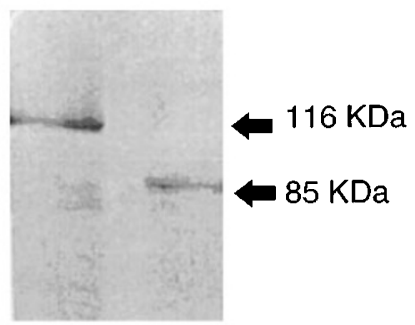

A
B

etoposide long-term

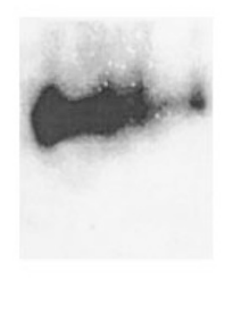

A $\quad F$

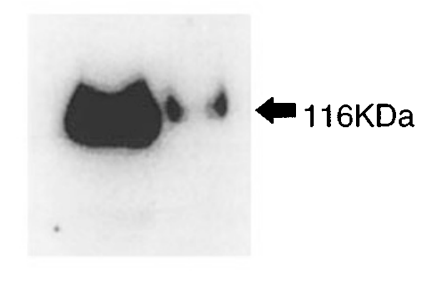

A

$\mathbf{F}$

Figure 4 Analysis of PARP proteolysis by Western blot (A) and of PARP autoribosylation by activity gel (B). For each experimental point, from HeLa apoptotic cell cultures two fractions were harvested: adherent cells $(\mathbf{A})$ and floating cells $(\mathbf{F})$. To induce apoptosis, cells were treated for $3 \mathrm{~h}$ with $100 \mu \mathrm{M}$ etoposide and further incubated for $24 \mathrm{~h}$ in fresh medium (etoposide) or cultured for up to 9 days in the same medium (long term). The bands of 116 and $89 \mathrm{KDa}$ represent intact and the proteolytic fragment of PARP, respectively

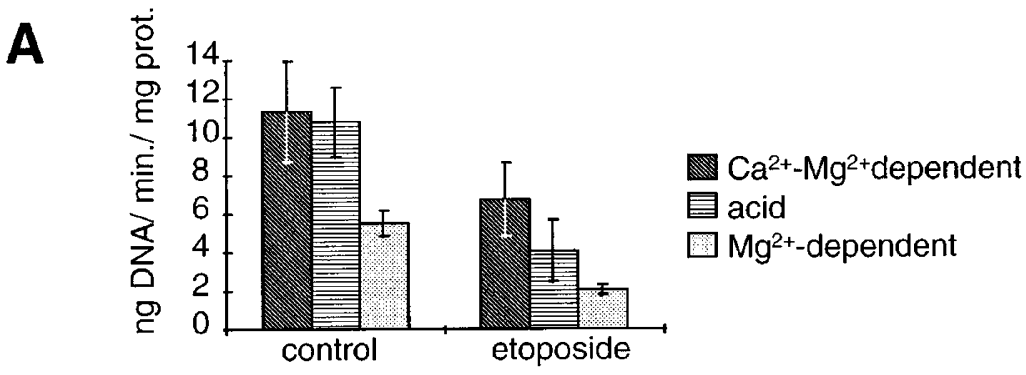

B

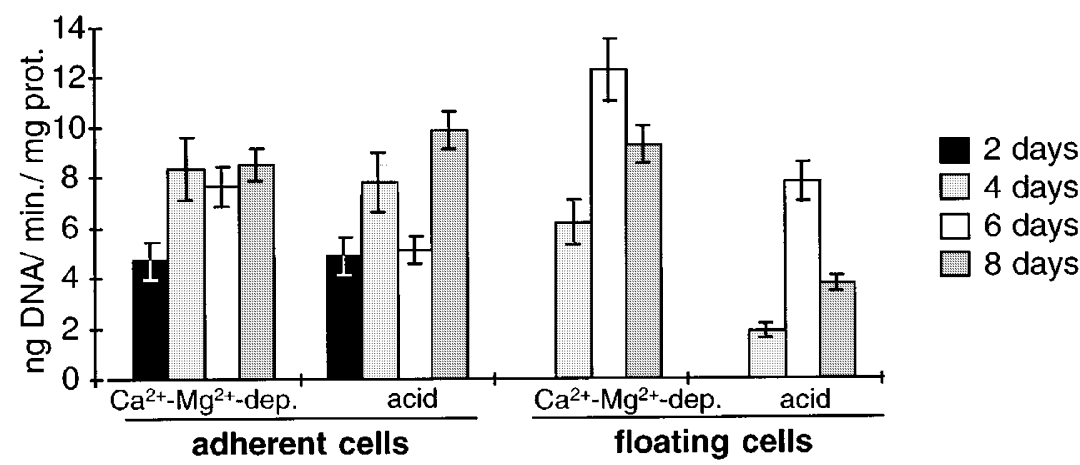

Figure 5 DNase activity of HeLa cell induced to die with etoposide $(\mathbf{A})$ or by long term-culture $(\mathbf{B})$. One $\mu \mathrm{g}$ of ${ }^{3} \mathrm{H}$-labeled DNA was incubated in the presence of HeLa cells extracts for $30 \mathrm{~min}$ at $37^{\circ} \mathrm{C}$. Different buffers were used to measure different DNases: $10 \mathrm{mM} \mathrm{Tris-HCl,} \mathrm{pH} 7.4$ containing $10 \mathrm{mM} \mathrm{CaCl}_{2}, 10 \mathrm{mM} \mathrm{MgCl} 2$

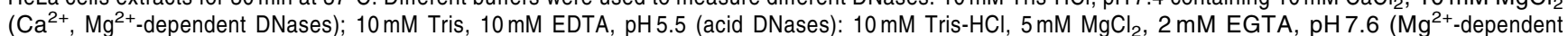
DNases). Undigested DNA was TCA-precipitated and measured with a $\beta$ scintillation counter. Etoposide-treated cells were incubated with $100 \mu \mathrm{M}$ etoposide for $3 \mathrm{~h}$ and further incubated in drug-free medium for $3 \mathrm{~h}$. For long term-cultured cells, adherent and floating cells were analyzed separately. DNase specific activity was expressed as ng of DNA digested/minute/mg of proteins 
A

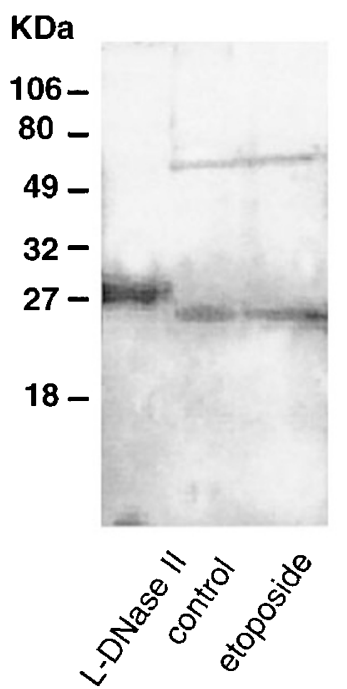

B

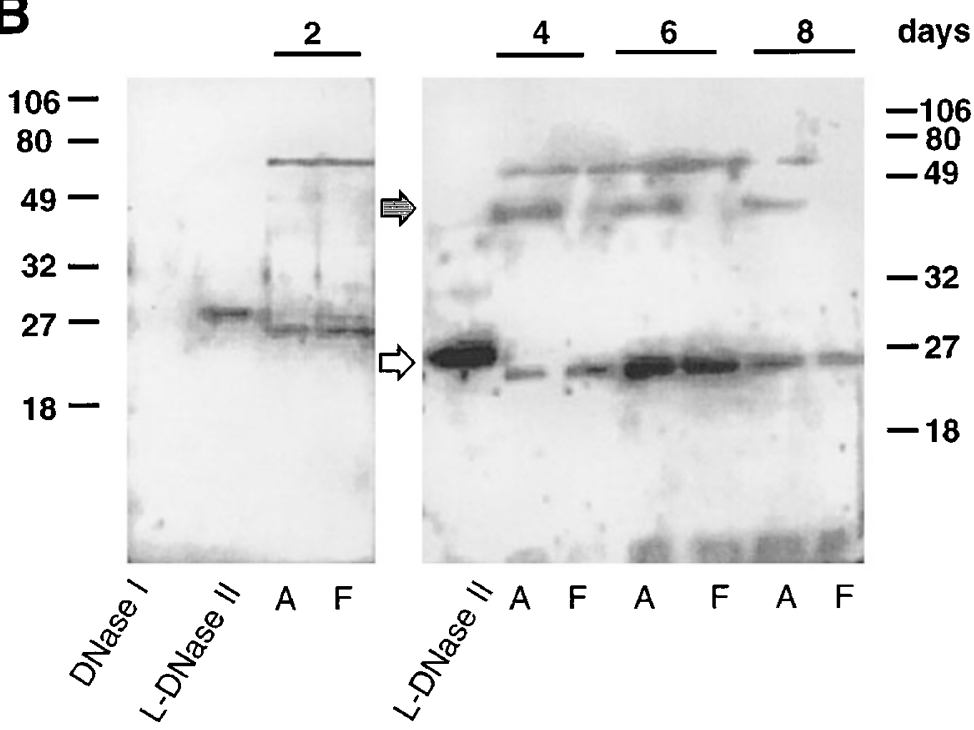

Figure 6 Western blot analysis of L-DNase II in HeLa cells induced to apoptosis by etoposide ( $100 \mu \mathrm{M}$, $3 \mathrm{~h}$, followed by $3 \mathrm{~h}$ of recovery) (A) or long term-culture ( 8 days) $(\mathbf{B})$. Adherent $(A)$ and floating $(F)$ cells were recovered and analyzed separately. Proteins from HeLa cells (100 $\mu \mathrm{g})$ were separated using $12 \%$ acrylamide slab gel, transferred to Immobilon P and developed using anti-L-DNase II. L-DNase II was used as a positive control. Purified DNase I was also loaded on the gel as a negative control. White arrow indicates the $25 \mathrm{KDa}$ active L-DNase II. Grey arrow indicates the $42 \mathrm{KDa}$ precursor of L-DNase II

Similar results were obtained for DNase I, when apoptosis was induced by long term-culture. In contrast, the induction of apoptosis by long term-culture showed apoptotic cells strongly labeled by anti-L-DNase II. Notably, the labeling was not confined to the cytoplasm but was extended also to the nucleus of the cells. Taken together, these results indicate that DNase II and $\mathrm{Ca}^{2+}-\mathrm{Mg}^{2+}$-dependent DNases, other than DNase I, are activated in HeLa cells when apoptosis is induced by long term-culture but not when it is induced with etoposide.

\section{Effect of caspase inhibitors}

To address whether the different expression of DNases might reflect the activation of two different apoptotic pathways or whether different enzymes might be recruited by the same activating pathway, we investigated the effect on apoptosis induced by etoposide or long term-culture of the synthetic peptide YVAD, used as an inhibitor of group 1 caspases. The expected effect of YVAD on TNF- $\alpha$-induced apoptosis has been verified (not shown). Drug-induced apoptosis was very sensitive to $20 \mu \mathrm{M}$ YVAD (Figure $8 \mathrm{~A}$ ), while apoptosis induced by long term-culture was resistant to this inhibitor, even when higher concentrations of YVAD $(60 \mu \mathrm{M})$ were used (Figure 8B). It is worth noting that in the presence of $60 \mu \mathrm{M}$ YVAD the percentage of apoptotic cells decreased slightly. However, higher concentrations of YVAD (up to $100 \mu \mathrm{M}$ ) did not enhance significantly this phenomenon (not shown). This result might reflect the activation of different pathways, leading to the activation of different endonucleases.

To verify this hypothesis, we measured the DNase activity of apoptotic floating cells after 6 days of culture in the presence or in the absence of $60 \mu \mathrm{M}$ YVAD (Figure $8 C)$. In the absence of YVAD, both $\mathrm{Ca}^{2+}-\mathrm{Mg}^{2+}$-dependent and acid endonucleases are activated. In contrast, in the presence of YVAD, only $\mathrm{Ca}^{2+}-\mathrm{Mg}^{2+}$-dependent endonucleases are inhibited but acid DNases are not sensitive to this inhibitor.

To investigate the correlation between caspase 1 and 3 activities, we have evaluated PARP proteolysis in both etoposide-treated and long term-cultured cells treated with YVAD. Western blot analysis revealed that PARP proteolysis occurs independently of caspase 1 inhibition (not shown).

\section{Discussion}

It is currently believed that different stimuli activate a common apoptotic pathway leading to the activation of degradative enzymes which kill the cell. ${ }^{28,29}$ These activities are presumed to be identical for all cell lines and all apoptotic stimuli. This assumption is based on morphological results which revealed similar features for apoptotic cells independently on the inducer. This is also the case of DNA ladder visualized by agarose gel electrophoresis or of cellular DNA content analyzed by flow cytometry.

Human cultured cells have been widely used to elucidate relevant features of the apoptotic process induced by several chemicals. ${ }^{30,31}$ To analyze the pattern of death induction by different stimuli in the same cell line, we have performed a set of experiments on HeLa cells induced to die by two ways: (i) etoposide administration, which is widely described apoptogenic treatment ${ }^{32,33}$ and (ii) long term-culture. ${ }^{34,35}$

Microscopical observation indicated that, during apoptosis induction by different ways, cells tend to detach from the solid support, to float in the medium and to show typical apoptotic markers. Morphological studies and internucleo- 
somal DNA degradation analysis revealed common features in etoposide-treated and long term-cultured HeLa cells. These features are not dependent of the cell cycle period in which apoptosis is induced as demonstrated by flow cytometry. Moreover, caspases 3 and 7 are activated in both systems, as demonstrated by PARP proteolysis. Remarkably, cleaved PARP is present almost exclusively in floating cells, which are, by consequence, devoid of PARP activity. We can state that this cell population, isolated both after etoposide administration and long term-culture as an effect of loss of cell adhesion, ${ }^{36}$ is enriched in apoptotic cells.

The study of DNA fragmentation by pulsed field gel electrophoresis showed in long term-cultures a degradation

\section{etoposide}
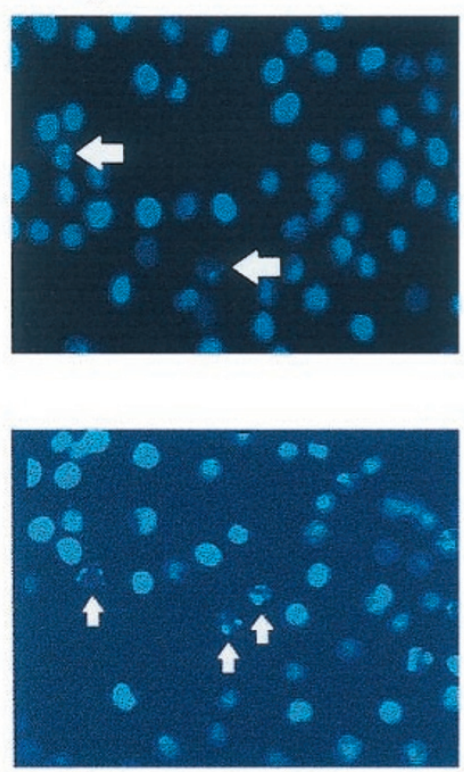

\section{long term-culture}
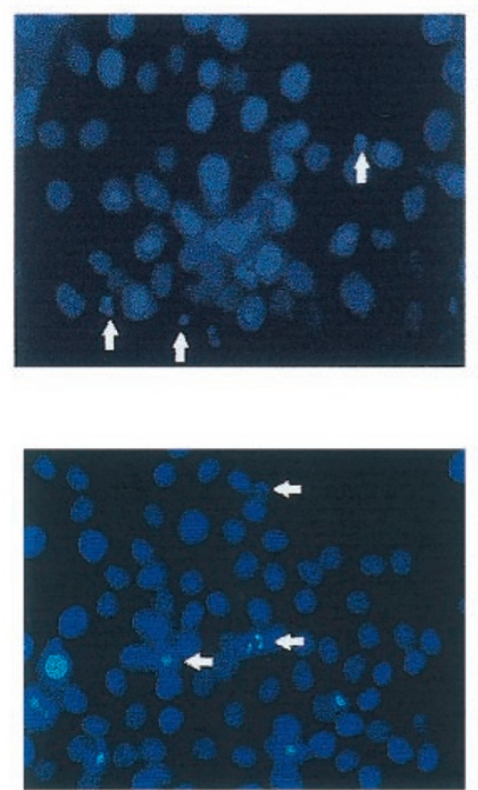
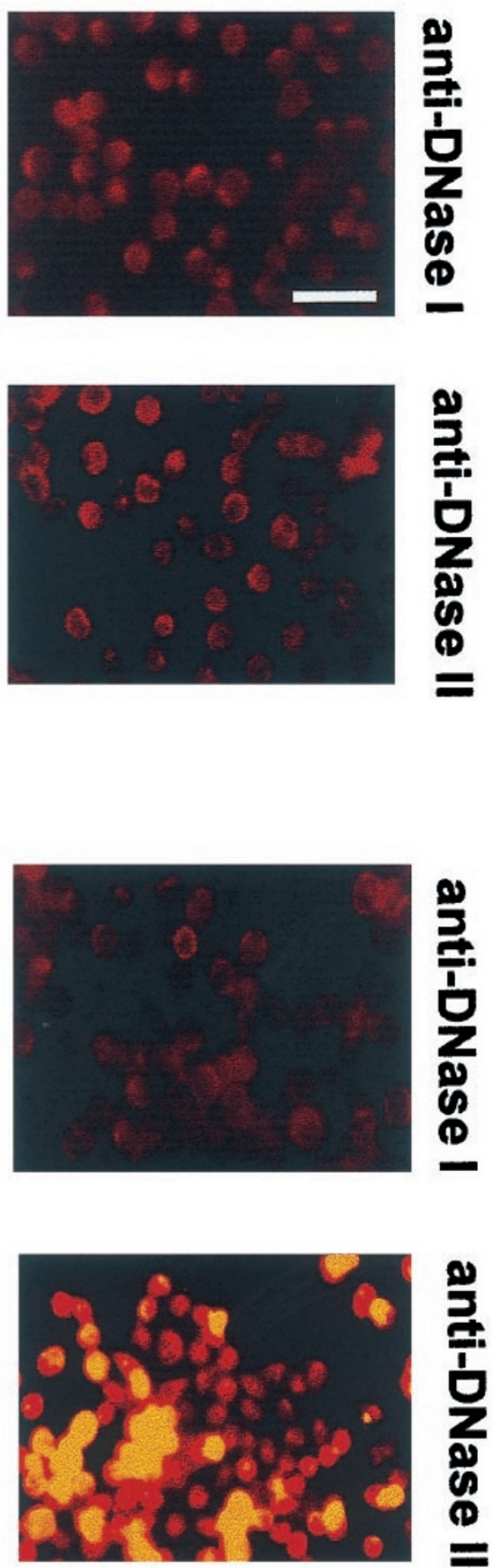

Figure 7 Immunocytochemistry of HeLa cells induced to apoptosis with etoposide ( $100 \mu \mathrm{M}, 3 \mathrm{~h}$, followed by $3 \mathrm{~h}$ of recovery) or long term-culture (8 days), using polyclonal antibodies to DNase I or L-DNase II. Cells were seeded on glass coverslips, cultured and induced to die. Nuclei were stained with DAPI. Anti-DNase I and anti-L-DNase II were localized using a secondary antibody coupled to rhodamine-isothiocyanate. Scale bar $=15 \mu \mathrm{m}$ 
A
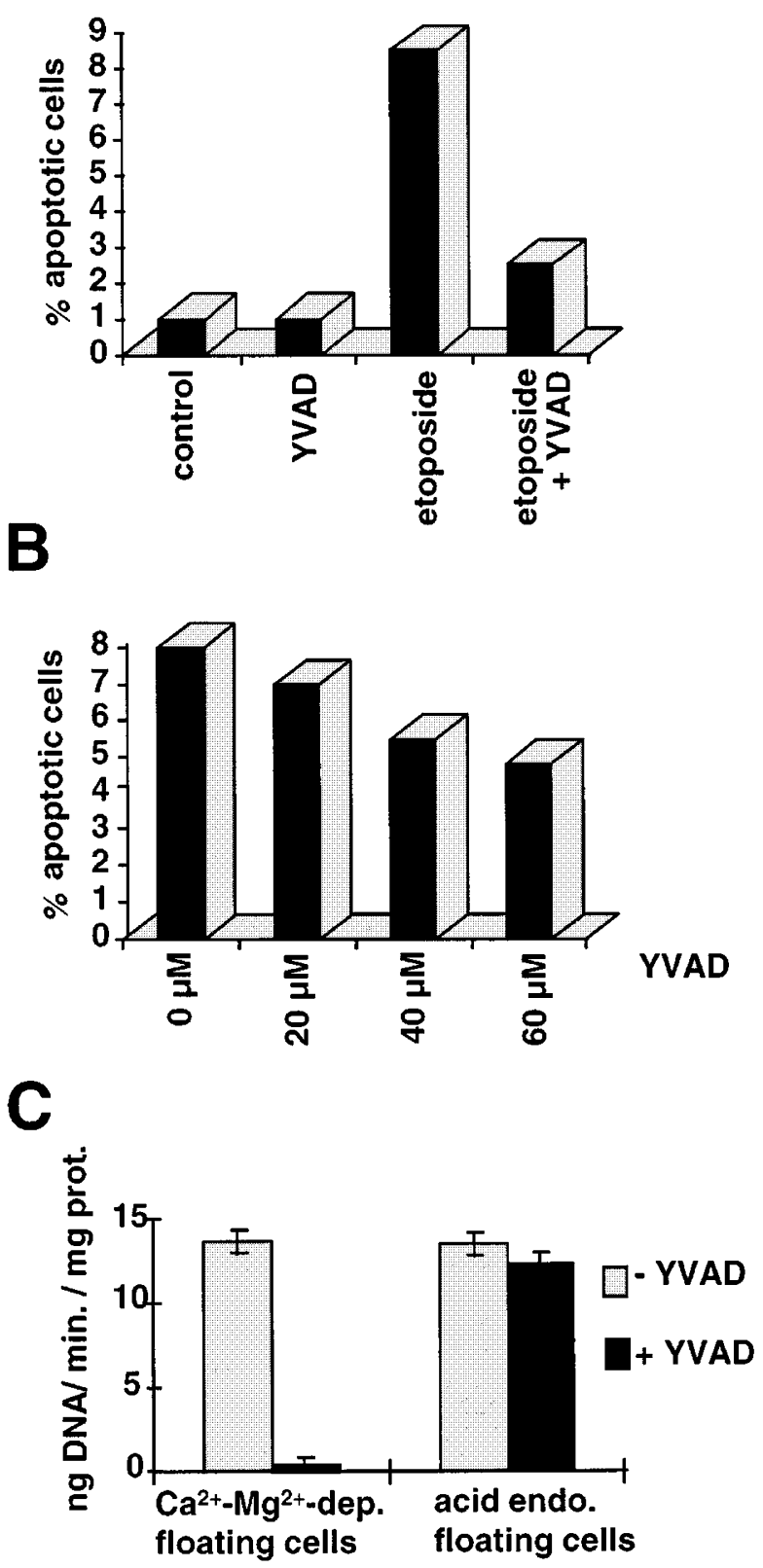

Figure 8 Effect of YVAD on HeLa cell apoptosis and DNase activity. HeLa cells were induced to apoptosis with etoposide (A) or long term-culture (B), in the presence or in the absence of YVAD. Apoptotic and living cells were counted after DAPI staining. (A) control: apoptotic index of control cells, YVAD: apoptotic index of cells incubated with $20 \mu \mathrm{M}$ YVAD. Etoposide: cells cultured in the presence of etoposide $(100 \mu \mathrm{M}, 3 \mathrm{~h}$, followed by $3 \mathrm{~h}$ of recovery). Etoposide+YVAD: cells preincubated for 30 min with $20 \mu \mathrm{M}$ YVAD, cultured in the presence of both $100 \mu \mathrm{M}$ etoposide and $20 \mu \mathrm{M}$ YVAD and maintained in the presence of YVAD for further $3 \mathrm{~h}$. (B) HeLa cells were cultured in the same medium for up to 8 days in the presence or in the absence of different concentrations of YVAD. (C) Activity of DNases in HeLa cells induced to die by long term-culture ( 6 days) in the presence or in the absence of $60 \mu \mathrm{M}$ YVAD. Extracts from floating cells were incubated with $1 \mu \mathrm{g}$ of ${ }^{3} \mathrm{H}$ labeled DNA for $30 \mathrm{~min}$ at $37^{\circ} \mathrm{C}$ in $10 \mathrm{mM}$ Tris- $\mathrm{HCl}, \mathrm{pH} 7.4$ containing $10 \mathrm{mM}$ $\mathrm{CaCl}_{2}, 10 \mathrm{mM} \mathrm{MgCl}_{2}\left(\mathrm{Ca}^{2+}, \mathrm{Mg}^{2+}\right.$-dependent DNases); or in $10 \mathrm{mM}$ Tris, $10 \mathrm{mM}$ EDTA pH5.5 (acid DNases). Undigested DNA was TCA-precipitated and measured with a $\beta$ scintillation counter. DNase specific activity was expressed as $\mathrm{ng}$ of DNA digested/minute/mg of proteins. Results of a representative experiment are shown pattern different from etoposide-treated cells, the latter system showing DNA fragments of $600 \mathrm{~Kb}$ certainly produced by the inhibition of topoisomerase II itself. The different degradation pattern may be ascribed to the activation of distinct endonucleases. To verify this hypothesis, we measured DNase activity and expression in both the experimental systems. During etoposide-induced apoptosis, we found no activation of the DNases to date believed to be implicated in apoptosis, ${ }^{6-12,24}$ whereas we observed that the induction of apoptosis by long termculture activated both $\mathrm{Ca}^{2+}-\mathrm{Mg}^{2+}$-dependent DNases and acid DNases. No increase in DNase I expression was noted, suggesting that $\mathrm{Ca}^{2+}-\mathrm{Mg}^{2+}$-dependent DNases other than DNase I are implicated in this phenomenon, as already reported by other authors. ${ }^{37}$ In contrast, as clearly visible in Western blot, the level of the active form of the acid L-DNase II (25 KDa) was greatly enhanced. This observation is in agreement with the increase in enzyme activity observed in extracts from cells maintained in culture for up to 6 days. These results are also supported by the immunocytochemical data which show a strong increase in L-DNase II labeling in long term culture-induced apoptosis. Note that cells not showing an apoptotic morphology are also labeled. In fact, Western blot analysis revealed also that after 4 days of cell culture, the attached cells synthesize the precursor of L-DNase II, ${ }^{27}$ a protein of $42 \mathrm{KDa}$, which is not visible in floating apoptotic cells showing all the precursor molecules converted to the active DNase.

Under these experimental conditions, the induction of apoptosis by long term-culture may occur in individual cells by different stimuli: metabolic stress produced by deprivation of nutrients and of growth factors, or synthesis of cell death molecules, like TNF- $\alpha$. It has been already shown that in different cell lines, including $\mathrm{HeLa}$, the induction of apoptosis by TNF- $\alpha$ activates $\mathrm{Ca}^{2+}-\mathrm{Mg}^{2+}$-dependent DNases. ${ }^{38}$ This event is inhibited by the caspases inhibitor YVAD. ${ }^{39}$ Under our experimental conditions, the use of this tetrapeptide strongly inhibits etoposide-induced apoptosis but, when used at the same concentration $(20 \mu \mathrm{M})$, has little effect on apoptosis induced by long-term culture. With higher concentrations of YVAD, up to $100 \mu \mathrm{M}$, a slight inhibitory effect can be noted. This phenomenon might reflect the existence of different pathways of apoptosis activated in different individual cells, depending on the nature of the apoptotic stimulus.

The activity of the $\mathrm{Ca}^{2+}-\mathrm{Mg}^{2+}$-dependent DNase is strongly inhibited in YVAD-treated cells while L-DNase II activity is not affected. This indicates that long term-culture activates in different individual cells different pathways. Likely, a pathway promoting the activation of $\mathrm{Ca}^{2+}-\mathrm{Mg}^{2+}$ dependent DNases is mediated by group 1 caspases while another, leading to the activation of L-DNase II, is independent on caspase 1.

The existence of distinct endonucleases activated by different stimuli has been already shown, as alternative pathways, in cells defective in one of them. ${ }^{40}$ Our results show that the same cell line is able to activate different apoptotic pathways even if it is not defective in one enzyme, according to the apoptotic inducer. 
From our data, caspase 3 and 7 seem to be activated in etoposide-treated and long-term cultured cells, while caspase 1 activity seems not to be involved in long termculture induced apoptosis, at least in the cells that activate L-DNase II. However, caspase 3 is considered to be activated downstream of caspase $1 .^{41-44}$ This suggests that this pathway is still activated in the cell but it is not the pathway that actually kills the cell, perhaps because it is not sufficient to mediate apoptosis in this metabolic state, as it has already been suggested in other cell lines. ${ }^{45}$ Alternatively, caspase 3 may be activated by a caspase 1independent pathway, also involved in the activation of LDNase II. This question is under current investigation.

Taken together, our results suggest the existence in the same cell line of diverse apoptotic pathways which can be achieved by different stimuli. These observations argue against the model of a single central apoptotic pathway within the cell. Moreover, our data demonstrate the involvement of L-DNase II in cell death by apoptosis occurring under 'physiological' conditions.

\section{Materials and Methods}

\section{Materials}

Etoposide was obtained from Bristol Italiana; low melting agarose, 4',6-diamidino-2-phenylindole (DAPI) and Hoechst 33258 were purchased from Sigma; RNase $A$ and RNase $T_{1}$, proteinase $K$ and DNA molecular weight marker VI were from Boehringer. Lambda DNA ladder PFGE marker was from New England Biolabs. Agarose for conventional and pulsed-field gel electrophoresis were from Pharmacia and Sigma, respectively. Nitrocellulose and pre-stained molecular weight markers for electrophoresis were from BioRad. The scintillation liquid was Luma Safe from Packard. Immobilon P and GF/ $C$ filters were obtained from Millipore. TRITC-conjugated and peroxidase-conjugated goat anti-rabbit $\lg G$ were from Biosys. Alkaline phosphatase-conjugated goat anti-mouse IgG and BCIPNBT revelation system were purchased from Promega. Tumor necrosis factor $\alpha(T N F \alpha)$ was obtained from Genzyme. The tetrapeptide ICE-inhibitor, Ac-YVAD-CHO was from Calbiochem. Purified DNase I and II were from Sigma and Worthington, respectively. Polyclonal antibody against DNase I was from Rockland. Polyclonal antibody against L-DNase II was prepared in our laboratory ${ }^{24}$ as well as the labeled calf thymus DNA (Pharmacia) used in DNase activity assay. Monoclonal antibody C-2-10 against poly(ADP-ribose) polymerase, which recognizes an epitope located between the DNA binding domain and the automodification domain, was provided by Dr. Guy Poirier, Université Laval, Québec. Deoxy [8- ${ }^{3} \mathrm{H}$ ] adenosine $5^{\prime}$ triphosphate, ammonium salt (code TRK 34 , $777 \mathrm{GBq} / \mathrm{mmol})$ was from Amersham, ${ }^{32} \mathrm{P}-\mathrm{NAD}(800 \mathrm{Ci} / \mathrm{mmol})$ was a NEN-Life Science product.

\section{Cell culture}

HeLa S3 cells were grown as monolayer in Dulbecco's modified Eagle's medium (D-MEM, GIBCO-BRL) supplemented with 10\% fetal calf serum (FCS; HyClone, Logan, UT, USA), $4 \mathrm{mM}$ glutamine, $2 \mathrm{mM}$ sodium pyruvate, $100 \mathrm{U} / \mathrm{ml}$ penicillin and $0.1 \mathrm{mg} / \mathrm{ml}$ streptomycin (all from GIBCO-BRL). Cells were grown at $37^{\circ} \mathrm{C}$ in a humidified atmosphere containing $5 \% \mathrm{CO}_{2}$.

\section{Cell treatment}

HeLa cells were seeded at a concentration of $3 \times 10^{5}$ cells $/ \mathrm{ml}$, maintained in culture for 3 days and then treated for $3 \mathrm{~h}$ with $100 \mu \mathrm{M}$ etoposide. Thereafter, cells were washed with Phosphate Buffered Saline (PBS) to remove the drug, and harvested immediately or maintained in culture with fresh medium for different time periods $(3 \mathrm{~h}$ and $24 \mathrm{~h})$. For long term-culture experiments, HeLa cells were trypsinized and seeded at $1 \times 10^{5} / \mathrm{ml}$, maintained in culture without changing the medium and harvested at different times up to 10 days. The fraction of cells detached from the solid support at the end of each treatment was recovered and further analyzed separately from still adherent cells.

\section{Analysis of cell morphology}

Apoptotic cells were identified through microscopic observation of samples stained with Hoechst 33258 . The analysis was performed directly on HeLa cells previously seeded on glass coverslips. For the fraction of HeLa cells detached at the end of the treatments, a further step of cytocentrifugation on glass slips at 500 r.p.m. for $3 \mathrm{~min}$ in PBS containing $10 \%$ FCS at a concentration of $10^{6} \mathrm{cells} / \mathrm{ml}$ was applied. Cells were then fixed for 10 min with ice-cold $70 \%$ ethanol and then washed several times with ice-cold PBS. DNA was stained with $0.1 \mu \mathrm{g} /$ $\mathrm{ml} \mathrm{Hoechst} 33258$ for $10 \mathrm{~min}$ at room temperature. The number of apoptotic cells was evaluated through fluorescence observation using a Leitz Orthoplan microscope equipped with a 50X objective. For each sample, 500 cells were counted. Pictures were obtained using Kodak Tmax (400 ASA) b/w film.

For immunofluorescence experiments, HeLa cells were seeded on coverslips at a concentration of $10^{5}$ cells $/ \mathrm{ml}$, maintained in culture for 3 days and treated as above. In some experiments, cells still adherent to the solid support and floating cells were harvested separately. Floating cells were fixed in paraformaldehyde and spread on a glass coverslip before immunological analysis.

\section{Flow cytometry}

Flow cytometric detection of DNA fragmentation was performed on cells fixed in $70 \%$ ethanol. Samples were stained for $30 \mathrm{~min}$ with $50 \mu \mathrm{g} / \mathrm{ml}$ propidium iodide in $10 \mathrm{mM}$ Tris $-\mathrm{HCl}, \mathrm{pH} 7.4$ containing $100 \mathrm{U} / \mathrm{ml}$ RNase A. Measurements and further analysis were performed with a Coulter Epics XL (Coulter, CO, USA) flow cytometer. Ten thousand cells were measured for each sample. ${ }^{46}$ Percentage of cells in each phase was calculated by using the software provided with the instrument.

\section{Analysis of DNA fragmentation}

Cells were rinsed twice in cold PBS containing $5 \mathrm{mM}$ EDTA. To analyze high molecular weight DNA fragmentation, pulsed-field gel electrophoresis was applied. ${ }^{47} 2.5 \times 10^{6}$ cells were embedded in agarose plug as previously described. ${ }^{35}$ The run was performed by a CHEF-DRII electrophoresis system (BioRad, Hercules, USA) at $14^{\circ} \mathrm{C}$ in $0.5 \times$ TAE buffer with ramped switch time from $20-40 \mathrm{~s}$ over $20 \mathrm{~h}$. Constant voltage ( 160 volts) was applied throughout the total run time, Gel was stained with $0.5 \mu \mathrm{g} / \mathrm{ml}$ ethidium bromide in $0.5 \times \mathrm{TAE}$ and DNA was visualized by UV transillumination. Twenty-one successive concatamers of lambda DNA were used as marker, the lowest band corresponding to $48.5 \mathrm{~Kb}$. To visualize internucleosomal DNA fragmentation, genomic DNA was extracted from $10^{7}$ cells as described by Herrmann et al. ${ }^{48}$ with minor modifications ${ }^{49}$ and analyzed by conventional gel electrophoresis. 


\section{Analysis of PARP proteolysis and autoribosylation}

Extracts from still adherent and floating cells were prepared according to Shah et al. ${ }^{50}$ and were further used for the analysis of the structural and catalytical properties of PARP, by Western blot and activity gel respectively.

For Western blot anlaysis, an equal amount of cells was loaded onto a $7.5 \%$ SDS-polyacrylamide gel and electrophoresed under standard conditions. Proteins were transferred onto a nitrocellulose membrane according to Towbin et al. ${ }^{51}$ The incubation with C-2-10 monoclonal antibody against PARP, diluted 1:10000 in PBS containing $10 \%$ newborn calf serum and $0.2 \%$ Tween-20, was carried out for $3 \mathrm{~h}$ at r.t. and was followed by the incubation with the secondary antibody conjugated with alkaline phosphatase. Visualization of the immunoreactive peptides was performed using a BCIP/NBT color development substrate according to the manufacturer's protocol.

The PARP activity gel procedure was carried out on the same extracts analyzed by Western blot. The protocol implies SDS-PAGE, in situ renaturation of proteins, incubation of the gel with ${ }^{32} \mathrm{P}-\mathrm{NAD}$, removal of non-incorporated substrate and autoradiography. ${ }^{52,53}$ The radioactive band at $116 \mathrm{KDa}$ represents automodified PARP.

\section{Preparation of HeLa extracts for DNase activity measurements}

HeLa cells $\left(6 \times 10^{7}\right)$ were homogenized in ice in $2 \mathrm{ml}$ of $10 \mathrm{mM}$ Tris$\mathrm{HCl}, \mathrm{pH} 7.4$ containing $1 \mathrm{M} \mathrm{NaCl}$, using a Potter homogenizer, and disrupted in a sonication bath for $15 \mathrm{~min}$. The homogenate was then centrifuged $\left(10000 \times g, 4^{\circ} \mathrm{C}\right)$ for $30 \mathrm{~min}$. The supernatant was dialyzed overnight against $10 \mathrm{mM}$ Tris- $\mathrm{HCl}, 1 \mathrm{mM}$ EDTA, $\mathrm{pH} 7.4$ at $4^{\circ} \mathrm{C}$, overnight. Protein concentration was evaluated with the $\mathrm{BCA}$ method (Pierce), using bovine serum albumin (BSA) as standard.

\section{Measurement of DNase activities}

Acid DNase II activity was measured in $200 \mu \mathrm{l}$ of $10 \mathrm{mM}$ Tris- $\mathrm{HCl}$ buffer containing $10 \mathrm{mM}$ EDTA, pH 5.75. $\mathrm{Ca}^{2+}-\mathrm{Mg}^{2+}$-dependent DNase activity was measured in $200 \mu \mathrm{l}$ of $10 \mathrm{mM}$ Tris- $\mathrm{HCl}, \mathrm{pH} 7.4$ containing $10 \mathrm{mM} \mathrm{CaCl}$ and $10 \mathrm{mM} \mathrm{MgCl}_{2}$, while $\mathrm{Mg}^{2+}$-dependent DNases were measured in $10 \mathrm{mM}$ Tris, $2 \mathrm{mM}$ EGTA, $5 \mathrm{mM} \mathrm{MgCl}_{2}$. The reaction, started with $1 \mu \mathrm{g}{ }^{3} \mathrm{H}$-DNA, was allowed to proceed for $30 \mathrm{~min}$ at $37^{\circ} \mathrm{C}$, then stopped by precipitation for $1 \mathrm{~h}$ at $0^{\circ} \mathrm{C}$ with $200 \mu \mathrm{l}$ of $10 \%$ trichloroacetic acid (TCA) containing $1 \%$ sodium pyrophosphate $\left(\mathrm{PP}_{\mathrm{i}}\right)$. The non digested DNA was then collected on a GF/C filter previously embedded in $1 \% \mathrm{PP}_{\mathrm{i}}$, rinsed five times with $2 \mathrm{ml}$ of $5 \%$ TCA containing $1 \% \mathrm{PP}_{\mathrm{i}}$, twice with $2 \mathrm{ml}$ of $100 \%$ ethanol and air dried. Radioactivity was quantified in a beta scintillation counter.

\section{Immunoblotting detection of DNases}

Protein samples for electrophoresis were prepared according to Laemmli. ${ }^{54} \mathrm{Gel}$ electrophoresis was conducted at a constant current of $20 \mathrm{~mA}$ using $12 \%$ polyacrylamide slab gels. Prestained high molecular weight markers (Biorad) were used for gel calibration. Transfer of proteins to Immobilon $\mathrm{P}$ membranes was carried out electrophoretically. ${ }^{51}$ A constant voltage of $40 \mathrm{~V}$ was applied for $16 \mathrm{~h}$. Immediately after blotting the membranes were soaked for $2 \mathrm{~h}$ at $37^{\circ} \mathrm{C}$ in PBS containing $5 \%$ fat free dried milk. Thereafter, the blot was incubated for $1 \mathrm{~h}$ at room temperature with anti-DNase I antibody $(80 \mu \mathrm{g} / \mathrm{ml})$ or anti-L-DNase II antibody diluted (1/150) in PBS containing $0.5 \%$ fat free dried milk (PM buffer). Controls are incubated with an equivalent dilution of rabbit preimmune serum. The binding of the antibodies was visualized after two washings (10 min each) with PM buffer, followed by $1 \mathrm{~h}$ incubation with peroxidase-conjugated goat anti-rabbit IgG $(1 \mu \mathrm{g} / \mathrm{ml})$ in PM buffer. The sheets were then rinsed successively with PM buffer $(2 \times 5 \mathrm{~min})$, PBS containing $0.1 \%$ Tween $20(2 \times 5 \mathrm{~min})$ and finally with PBS $(2 \times 5 \mathrm{~min})$. Peroxidase activity was detected using the ECL method (Amersham).

\section{Immunohistochemical analysis of DNases}

Cells were fixed in $3 \%$ paraformaldehyde for $10 \mathrm{~min}$, washed in PBS and permeabilized with $0.3 \%$ Triton X-100 in PBS for $30 \mathrm{~min}$. After washing with BPS, samples were saturated for $30 \mathrm{~min}$ at room temperature with PBS containing $1 \%$ milk and then incubated for $1 \mathrm{~h}$ at room temperature with the specific antisera (diluted 1/150). This incubation was followed by five washings for $5 \mathrm{~min}$ in PBS-milk. The immunological reaction was visualized using a TRITC-conjugated goat anti-rabbit IgG diluted 1/200 in PBS-milk (1 h, room temperature). Cells were then washed five times for $5 \mathrm{~min}$ in PBS and nuclei were stained with the fluorescent nuclear stain 4',6-diamidino-2-phenylindole (DAPI). Coverslips were then mounted with PBS containing 50\% glycerol. Fluorescence was examined under a Leitz Aristoplan microscope equipped with an epi-illuminator HBO and filters for Rhodamine and DAPI fluorescence. Samples were photographed using an Ilford HP5 film (400 ASA).

\section{Inhibition of apoptosis with YVAD}

Cells were pre-treated with $20 \mu \mathrm{M}$ YVAD for 30 min before etoposide administration (etoposide, $100 \mu \mathrm{M}$ for $3 \mathrm{~h}$ ) in the presence of $20 \mu \mathrm{M}$ YVAD. After drug removal, fresh medium was further supplemented with $20 \mu \mathrm{M}$ YVAD. Twenty-four hours later, cells were harvested and apoptotic features were quantified by DAPI or Hoechst staining. For long term-culture experiments, increasing concentrations of YVAD $(20-100 \mu \mathrm{M})$ were added to the culture medium from day 4 to day 8 . As a control of YVAD inhibition of apoptosis, cells were treated in independent experiments with $0.1-50 \mathrm{ng} / \mathrm{ml} \mathrm{TNF} \alpha$ for $72 \mathrm{~h}$.

\section{Acknowledgements}

We thank Dr. Guy Poirier (Université Laval, Québec) for the monoclonal antibody C-2-10. A.T. was recipient of a Rhöne-Poulenc-Roerer and a Fondation Fouassier fellowships; C.N. was a FIRC and Claude Bernard fellow. This work has been partially supported by the CNR/INSERM program no. 132.22.

\section{References}

1. Vaux DL and Strasser A (1996) The molecular biology of apoptosis. Proc. Natl. Acad. Sci. USA 93: 2239-2244

2. Cain K, Inayat-Hussain SH, Wolfe JT and Cohen GM (1994) DNA fragmentation into $200-250$ and/or $30-50$ kilobase pair fragments in rat liver nuclei is stimulated by $\mathrm{Mg}^{2+}$ alone and $\mathrm{Ca}^{2+} / \mathrm{Mg}^{2+}$ but not by $\mathrm{Ca}^{2+}$ alone. FEBS Lett. 349: $385-391$

3. Cohen GM, Sun XM, Fearnhead H, MacFarlane M, Brown DG, Snowden RT and Dinsdale D (1994) Formation of large molecular weight fragments of DNA is a key committed step of apoptosis in thymocytes. J. Immunol. 153: 507-516

4. Wyllie AH (1980) Glucocorticoid-induced thymocyte apoptosis is associated with endogenous endonuclease activation. Nature 284: $555-556$

5. Hewish DR and Burgoyne LA (1973) Chromatin sub-structure. The digestion of chromatin DNA at a regularly spaced sites by a nuclear deoxyribonuclease. Biochem. Biophys. Res. Commun. 52: 504-510

6. Montague JW, Gaido ML, Frye C and Cidlowski JA (1994) A calcium-dependent nuclease from apoptotic rat thymocytes is homologous with cyclophilin. Recombinant cyclophilins A, B and C have nuclease activity. J. Biol. Chem. 269: $18877-18880$ 
7. Peitsch MC, Polzar B, Stephan H, Crompton T, MacDonald HR, Mannherz HG and Tschopp J (1993) Characterization of the endogenous deoxyribonuclease involved in nuclear DNA degradation during apoptosis (programmed cell death). EMBO J. 12: $371-377$

8. Shiokawa D, Ohyama H, Yamada T, Takahashi K and Tanuma S-I (1994) Identification of an endonuclease responsible for apoptosis in rat thymocytes. Eur. J. Biochem. 226: 23-30

9. Pandey S, Walker PR and Sikorska M (1997) Identification of a novel $97 \mathrm{KDa}$ endonuclease capable of internucleosomal DNA cleavage. Biochemistry 36 : $711-720$.

10. Kawabata H, Anzai N, Masutani H, Hirama T, Yoshida Y and Okuma M (1993) Detection of $\mathrm{Mg}^{2+}$-dependent endonuclease activity in myeloid leukemia cell nuclei capable of producing internucleosomal DNA cleavage. Biochem. Biophys. Res. Comm. 191: 247-254

11. Kawabata H, Anzai N, Masutani H, Hirama T, Hishita T, Dodo M, Masuda $T$, Yoshida $\mathrm{Y}$ and Okuma M (1997) $\mathrm{Mg}^{2+}$ or $\mathrm{Mn}^{2+}$-dependent endonuclease activities of human myeloid leukemia cells capable of producing nucleosomalsize DNA fragmentation. Biochem. Biophys. Res. Comm. 233: 133-138

12. Barry MA and Eastman A (1993) Identification of deoxyribonuclease II as an endonuclease involved in apoptosis. Arch. Biochem. Biophys. 300: 440-450

13. Pérez-Sala D, Collado-Escobar D and Mollinedo F (1995) Intracellular alkalinization suppresses Lovastatin-induced apoptosis in $\mathrm{HL}-60$ cells through the inactivation of a pH-dependent endonuclease. J. Biol. Chem. 270: 62356242

14. Wolf CM, Morana SJ and Eastman A (1997) Zinc inhibits apoptosis upstream of ICE/CED-3 proteases rather than at the level of an endonuclease. Cell Death Diff. 4: 125-129

15. Rosen A and Casciola-Rosen L (1997) Macromolecular substrates for the ICElike proteases during apoptosis. J. Cell Biochem. 64: 50-54

16. Alnemri ES, Livingston DJ, Nicholson DW, Salvesen G, Thornberry NA, Wong WW and Yuan J (1996) Human ICE/CED-3 protease nomenclature. Cell 87: 171

17. Kaufmann SH, Desnoyers S, Ottaviano Y, Davidson NE and Poirier GG (1993) Specific proteolytic cleavage of poly(ADP-ribose) polymerase: an early marker of chemotherapy-induced apoptosis. Cancer Res 53: 3976-3985

18. Cohen GM (1997) Caspases: the executioners of apoptosis. Biochem. J. 326 $1-16$

19. Thornberry NA and Lazebnik Y (1998) Caspases: ennemies within. Science 281 1312-1316

20. Nicholson DW, Ali A, Thornberry NA, Vaillancourt JP, Ding CK, Gallant M, Gareau Y, Griffin PR, Labelle M, Lazebnik YA, Munday NA, Raju SM, Smulson ME, Yamin T-T, Yu VL and Miller DK (1995) Identification and inhibition of the ICE/CED-3 protease necessary for mammalian apoptosis. Nature 376: $37-43$

21. Enari M, Sakahira H, Yokoyama H, Okawa K, Iwamatsu A and Nagata S (1998) A caspase-activated DNase that degrades DNA during apoptosis, and its inhibito ICAD. Nature 391: 43-50

22. Sakahira H, Enari M and Nagata S (1998) Cleavage of CAD inhibitor in CAD activation and DNA degradation during apoptosis. Nature 391: 96-99

23. Halenbeck R, MacDonald $H$, Roulston A, Chen TT, Conroy L and Williams LT (1998) CPAN, a human nuclease regulated by the caspase-sensitive inhibitor DFF45. Curr. Biol. 8: 537-540

24. Torriglia A, Chaudun E, Chany-FournierF, Jeanny JC, Courtois Y and Counis MF (1995) Involement of DNase II in nuclear degeneration during lens cel differentiation. J. Biol. Chem. 270: 28579-28585

25. Liao T-H(1985) The subunit structure and active site sequence of porcine spleen deoxyribonuclease. J. Biol. Chem. 260: 10708-10713

26. Yasuda T, Takeshita H, lida R, Nakajima T, Hosomi O, Nakashima Y and Kishi K (1998) Molecular cloning of the cDNA encoding human deoxyribonuclease II. J. Biol. Chem. 273: 2610-2616

27. Torriglia A, Perani P, Brossas JY, ChaudunE, Tréton J, Courtois Y and Counis MF (1998) L-DNase II, a molecule that links proteases and endonucleases in apoptosis, derives from the ubiquitous serpin leukocyte elastase inhibitor. Mol. Cell. Biol. 18: 3612-3619

28. Golstein P (1997) Controlling cell death. Science 275: 1081-1082

29. Rudin CM and Thompson CB (1997) Apoptosis and disease: regulation and clinical relevance of programmed cell death. Annu. Rev. Med. 48: 267-281

30. Korsmeyer SJ (1995) Regulators of cell death. Trends Genet. 11: 101-105

31. Wertz IE and Hanley Mr (1996) Diverse molecular provocation of programmed cell death. Trends Biochem. Sci. 21: 359-364
32. Zhang H, D'Arpa P and Liu LF (1990) A model for tumor cell killing by topolsomerase poisons. Cancer Cells 2: 23-27

33. Sen S and D'Incalci M (1992) Apoptosis. Biochemical events and relevance to cancer chemotherapy. FEBS Lett. 307: 122-127

34. Rinner I, Kukulansky T, Felsner P, Skreiner E, Globerson A, Kasai M, Hirokawa K, Korsatko W and Schauenstein K (1994) Cholinergic stimulation modulates apoptosis and differentiation of murine thymocytes via a nicotinic effect on thymic epithelium. Biochem. Biophys. Res. Commun. 203: 1057-1062

35. Negri C, Bernardi R, Donzelli M, Prosperi E and Scovassi Al (1996) Sequence of events leading to apoptosis in long term cultured Hela cells. Cell Death Differ. 3: $425-429$

36. Whitacre CM and Berger NA (1997) Factors affecting topotecan-induced programmed cell death: adhesion protects cells from apoptosis and impairs cleavage of poly(ADP-ribose) polymerase. Cancer Res. 57: 2157-2163

37. Otto AM, Paddenberg R, Schubert S and Mannherz HG (1996) Cell-cycle arrest, micronucleus formation, and cell death in growth inhibition of MCF-7 breast cancer cells by tamoxifen and cisplatin. J. Cancer Res. Clin. Oncol. 122: 603612

38. Woo KR, Shu W-P, Kong L and Liu BC-S (1996) Tumor necrosis factor mediates apoptosis via $\mathrm{Ca}^{++} / \mathrm{Mg}^{++}$dependent endonuclease with protein kinase $\mathrm{C}$ as a possible mechanism for cytokine resistance in human renal carcinoma cells. J. Urol. 155: 1779-1783

39. Hisahara S, Shoji S, Okano H and Miura M (1997) ICE/CED-3 family executes oligodendrocyte apoptosis by tumor necrosis factor. J. Neurochem. 69: 10-20

40. Segal-Bendirdjian E and Jacquemin-Sablon A (1995) Cisplatin resistance in a murine leukemia cell line is associated with a defective apoptotic process. Exp. Cell. Res. 218: 201-212

41. Enari M, Hase A and Nagata S (1995) Apoptosis by a cytosolic extract from Fasactivated cells. EMBO J. 14: 5201-5208

42. Enari M, Talanian RV, Wong WW and Nagata S (1996) Sequential activation of ICE-like and CPP32-like proteases during Fas-mediated apoptosis. Nature 380: $723-726$

43. Rodriguez I, Matsuura K, Ody C, Nagata S and Vassalli P (1996) Systemic injection of a tripeptide inhibits the intracellular activation of CPP32-like proteases in vivo and fully protects mice against Fas-mediated fulminant liver destruction and death. J. Exp. Med. 184: 2067-2072

44. Peter ME, Heufelder AE and Hengartner MO (1997) Advances in apoptosis research. Proc. Natl. Acad. Sci. USA 94: 12736-12737

45. Vasilakos JP, Lynch T, Ghayur T, Giegel DA, Santoro M and Shivers BD (1997) Caspase-3/CPP32-like activity is not sufficient to mediate apoptosis in an IL-2 dependent T cell line. Apoptosis 2: 289-303

46. ProsperiE, Stivala LA, Sala E, Scovassi Al and Bianchi L (1993) Proliferating cell nuclear antigen complex formation induced by ultraviolet irradiation in human quiescent fibroblasts as detected by immunostaining and flow cytometry. Exp. Cell Res. 205: 320-325

47. Schwartz DC and Cantor CR (1984) Separation of yeast chromosome-sized DNAs by pulsed field gradient gel electrophoresis. Cell 37: 67-75

48. Herrmann M, Lorenz HM, Voll R, Grunke M, Woith W and Kalden JR (1994) A rapid and simple method for the isolation of apoptotic DNA fragments. Nucleic Acids Res. 22: 5506-5507

49. Donzelli M, Bernardi R, Negri C, Prosperi E, Padovan L, Lavialle C, Brison O and Scovassi Al (1998) Apoptosis-prone phenotype of human colon carcinoma cells with a high level amplification of the c-myc gene. Oncogene, in press

50. Shah GM, Poirier D, Duchaine C, Brochu G, Desnovers S, Lagueux J, Verreault A, HoflackJ-C, Kirkland JB and Poirier GG (1995) Methods for biochemical study of poly(ADP-ribose) metabolism in vitro and in vivo. Anal. Biochem. 227: 1-13

51. Towbin H, Staehelin T and Gordon J (1979) Electrophoretic transfer of proteins from polyacrylamide gels to nitrocellulose sheets: procedure and some applications. Proc. Natl. Acad. Sci. USA. 76: 4350-4354

52. Scovassi Al, Stefanini M and Bertazzoni U (1984) Catalytic activities of human poly(ADP-ribose) polymerase from normal and mutagenized cells detected after sodium dodecyl sulfate-polyacrylamide gel electrophoresis. J. Biol. Chem. 259: 10973-10977

53. Scovassi Al, Stefanini M, Lagomarsini P, Izzo R and Bertazzoni U (1987) Response of mammalian ADP-ribosyl transferase to lymphocyte stimulation, mutagen treatment and cell cycling. Carcinogenesis 9: 1295-1300

54. Laemmli UK (1970) Cleavage of structural proteins during the assembly of the head of bacteriophage T4. Nature 227: 680-685 